\title{
Welfare States and Care Arrangements: Care Time Mix Approach and Its Application to Japan and Korea
}

\author{
Mi Young An
}

School of Public Administration and Public Policy, Kookmin University

E-mail: myan@kookmin.ac.kr

This article suggests how notions of replacing, supplementing and valuing care by the family can be linked with policy instruments of childcare services, leave provisions, and cash for care by family, to influence care arrangements at collective and individual levels. It analyses care arrangements in Japan and Korea, estimating their changes over approximately ten years using the care time mix approach. The findings suggest that at the beginning of the new millennium, care arrangements in both countries were configured as female>non-state>male>state. A decade later, Japan remains the same, whereas Korea has become a paid care economy configured as non-state $>$ female $>$ male $>$ state. Unpaid care economy remains gendered, but over time, Japanese men's contribution has marginally increased, with the opposite being true in Korea. The article discusses what the transformation of the paid care economy in Korea, and its expansion in Japan, imply for social structures in the respective countries.

Key words: Care time mix, childcare, Japan, Korea.

\section{Introduction}

A generous family policy has been said to lead to higher employment rates for mothers (Huber and Stephens, 2001), and care services have been linked to cross-national variances in female employment (Anttonen and Sipilä, 1996). But women's higher paid employment has been shown to be compatible with a low degree of childcare services in Portugal (Tavora, 2012). For their part, An and Peng (2015) claim the relationship between employment rates and degree of childcare services does not explain the cross-national differences in the familialistic welfare states of Korea and Taiwan: Taiwan has the higher female employment rates with the lower childcare services, while Korea has the higher childcare service provisions and the lower female employment rate. Given these findings, it is no longer considered valid to assume linear positive effects of the degree of formal childcare on female economic autonomy in comparative analyses of welfare states.

Extending the first point, care analysis should not be limited to care as paid work; it should include care as unpaid work as well. Changes in state policies and programmes reflect the understanding of care as paid and unpaid work (Lewis, 1992). Yet we face critical questions, such as whether the growth of a paid care economy through outsourcing care decreases the family's contribution to the unpaid care economy. Studies have highlighted that welfare states both familialise and defamilialise care, with crossnational variances (Leitner, 2003; Szelewa and Polakowski, 2008) suggesting answers to the question are not straightforward. Another question is the possibility of differences 
within the family if we compare men and women. Again, comparative studies on welfare states and care indicate that we cannot assume the defamilisation of care through the provision of childcare services is good for gender equality, nor is the famililsation of care through leave provisions bad for it (Leitner, 2003; An and Peng, 2015).

Care is more than the object of policy-making; it also relates to a set of social relations involving power and dependency (Williams and Brennan, 2012: 356). Care is labour, an activity requiring money and time. Welfare states can therefore use care policies to draw a line between public and private spheres, determining care in different forms across macro institutional and micro individual/household levels (Daly and Lewis, 2000), changing the social structure (Pfau-Effinger, 2005) and influencing policy and politics.

This article suggests that welfare states can (re)configure caring responsibilities across institutions and individuals depending on whether they replace, supplement and/or value care by family. These 'care notions' are framed by existing welfare and gender understandings and are subject to change from the bottom and/or top. In the first section, we suggest the linking of care notions of replacing, supplementing and valuing care by the family to childcare services, leave provisions and financial support for care by the family can influence care arrangements at both collective and individual levels. As way of application, we compare and contrast care arrangements and the changes in the familialistic welfare regimes of Japan and Korea over time. Both were built on an unpaid care economy fuelled by the family, especially the women of the family. This paradigm is no longer sustainable, however, as the context of care has been changing, driven by demographic, economic and social factors, such as low fertility, ageing populations, increased women's paid work and changing norms of the role of women and family responsibilities. The two states have made marked policy interventions; social expenditures increased by 1 per cent of GDP between 1990 and 2011, surpassing the average of Organization of Economic Co-operation and Development countries namely, 0.6 per cent (OECD, 2015a). The second section discusses similarities and differences in childcare policies in Japan and Korea. In order to measure care arrangements at the collective and individual levels, we utilise the care time mix approach. The third section explains the usefulness and limitations of this approach, presenting data and measurements for the current analysis. This is followed by the results and a discussion of the implications for the two East Asian welfare states in particular and welfare states and care analysis in general.

\section{Welfare states and care arrangements}

The recent development of family policy, specifically childcare policy, has been the main subject of comparative welfare regime analyses. For example, Mahon et al. (2012) noted that childcare policies are converging at the level of ideas, with social democracies employing marketised services or market mechanisms, and liberal welfare regimes opting to increase public responsibilities. But diversity has continued in the way these ideas are translated into actual policies. Scholars have debated about the extent to which expansion affects policy changes. In the British case, Lewis and Campbell (2007) and Lewis (2013) saw changes in the paradigm, whereas Daly (2010) argued for a second order of policy instrument changes, with the British welfare regime remaining more or less intact.

With respect to gender and family, the notion of defamilialisation (the degree to which policies reduce familial dependency) has often been criticised for its ambiguity 
(Saxonberg, 2012; Ciccia and Bleijenbergh, 2014). Daly (2011) has claimed that defamilialisation is no longer a valid concept, as the family itself has been changing. More recently, Saxonberg (2012: 32) noted that as the main goal is to eliminate gender roles, and the need to genderalise welfare states stands at the centre of the feminist discourse on social policies, it makes sense to talk about genderalising and degenderalising rather than familialising and defamilialising. Scholars have often created 'terms' to posit conceptualisations of welfare states, including, for example, male breadwinner family model (Lewis, 1992); adult worker model (Lewis, 2001); general family support, dualearner support and market-orientated policies model (Korpi, 2000); family economy model, housewife model of the male breadwinner family, male breadwinner and female part-time carer model, dual breadwinner and external model, and dual breadwinner and dual carer model (Pfau-Effinger, 2005). However, less attention has been devoted to care as unpaid work at the macro collective level (what happens in unpaid care by family) and at the micro individual level (what happens between men and women within the family).

Pfau-Effinger (2005: 327-8) notes care arrangements overlap in a society's gender provisions and its welfare regime. More specifically, a welfare state plays a key role in the propagation of care arrangements, with policies of care based on welfare values (the state's overall vision of the provision of welfare) and family values (the structure of the family and the gender division of labour). We suggest childcare policies can be linked with care notions of replacing, supplementing and valuing care by family, and this influences care arrangements at both collective and individual levels. Defamilialising care (caring responsibilities are taken away from the family by outsourcing care) has been mostly, but not solely, oriented to the promotion of mothers' employment. In so doing, childcare policies could either replace the family and/or females' caring role or supplement it. In this process, paid care work increases. An and Peng (2015) suggested differentiating the provision-finance nexus in services into three: publicly financed and provided, publicly financed and privately provided and privately financed and provided childcare services. Welfare states may vary in their proportional shares of the provisionfinance nexus. Replacing care by family means the welfare state organises non-family care by providing publicly financed services to ensure affordable, universal and good quality service. Although childcare policies aim to encourage women's involvement in paid employment, political orientations go beyond viewing childcare services as 'instruments'. The ideational sense of the primary location of care can no longer be perceived as the family and/or women.

In contrast, supplementing care by the family means the welfare state organises non-family care to argument the role of family which takes the primary responsibility in childcare arrangements through publicly financed and privately provided services. Public financial support can offset some of the costs of raising children (Mahon, 2002) through such public financing as subsidies, but the ideational sense of the primary location of care remains the family. The ideational orientation leads to the provision of financial support to encourage the use of services provided by non-state providers, including, for example, for-profit and non-profit providers. Supporters of marketisation or the market mechanism believe this is a better way to ensure the quality of services, cost-effectiveness and users' empowerment through the exercise of choice. Because of market providers' profit-seeking behaviours, however, accessibility to services is limited, as it is determined by the individual's or the family's ability to pay. In addition, the quality of service is inherently diverse and unevenly distributed among different areas or classes, as choices 
in market provision tend to focus on well-equipped markets with more resources. Williams and Brennan (2012) suggest quality is often put aside in the care market for the sake of cost reductions by hiring low qualified and less skilled workers.

Welfare states also familialise care by valuing the role of family to provide unpaid care work. Daly (2011: 7) notes that welfare states promote family as a way of life and a force for social integration; therefore, familialisation remains an important concept against which policy changes should be analysed. As ways to value care as unpaid work, welfare states employ leave provisions and/or financial support for care at home (An and Peng, 2015).

To reiterate, care arrangements refer to the way care is configured as paid or unpaid work at the collective level of institutions and at the individual level between men and women within the family. Welfare state policies are pivotal for sustaining or altering existing arrangements, and are driven by notions of replacing, supplementing and/or valuing care by the family.

State policy can be divided into two approaches. The first is driven by the notion of replacing family care through publicly financed provided services and/or valuing family care through leave provisions. The second follows notions of supplementing family care through publicly financed and privately provided services and/or valuing care by family through financial support. At the institutional level, in the first approach, a larger portion is assumed by the state than by non-state formal institutions. In the second approach, a larger portion is assumed by non-state institutions. In both approaches, the unpaid care economy could be larger or smaller than the paid care economy.

At the individual level, the first approach has relatively strong implications for the equal division of unpaid care work. It should be noted that women's gainful engagement in the labour market does not automatically and positively relate to an equal division of unpaid work within the family. In this approach, women's labour can be viewed as an important resource for the national economy and gender equality. Thus, provisions tend to protect employment status and wages, arguably giving working mothers more bargaining power (Lundberg and Pollak, 1996) so they can reduce their participation in care compared to their male partners, and/or encouraging men to be involved in caring labour. In addition, familisation through leave provisions may value the right of working mothers to take time off to care for family and, at the same time, encourage fathers to be carers, thus directly influencing the degendering of unpaid care work.

By contrast, the second approach has weak potential to alter the gender division of labour in unpaid care work. Supplementing care through publicly financed and privately provided care, and/or valuing care by the family through allowances, sustains the normative assumption that the family should assume primary responsibility. Familisation by providing care allowances may gender the unpaid care work. The second approach, thus, may reinforce the traditional division of labour.

In the first approach, welfare states have the potential to generate a universal carer model. As this approach attempts to replace and/or value care through leave provisions, it can generate a supported dual earner and female caregiver model or a supported one and a half earner and female caregiver model. Meanwhile, the second approach rarely creates a universal carer model. It might generate an unsupported dual earner and female caregiver model, or an unsupported one and a half earner and female caregiver model, or even a male breadwinner and supported female caregiver model. One specific family model may be dominant in a given society, or different family models may co-exist (Pfau- 


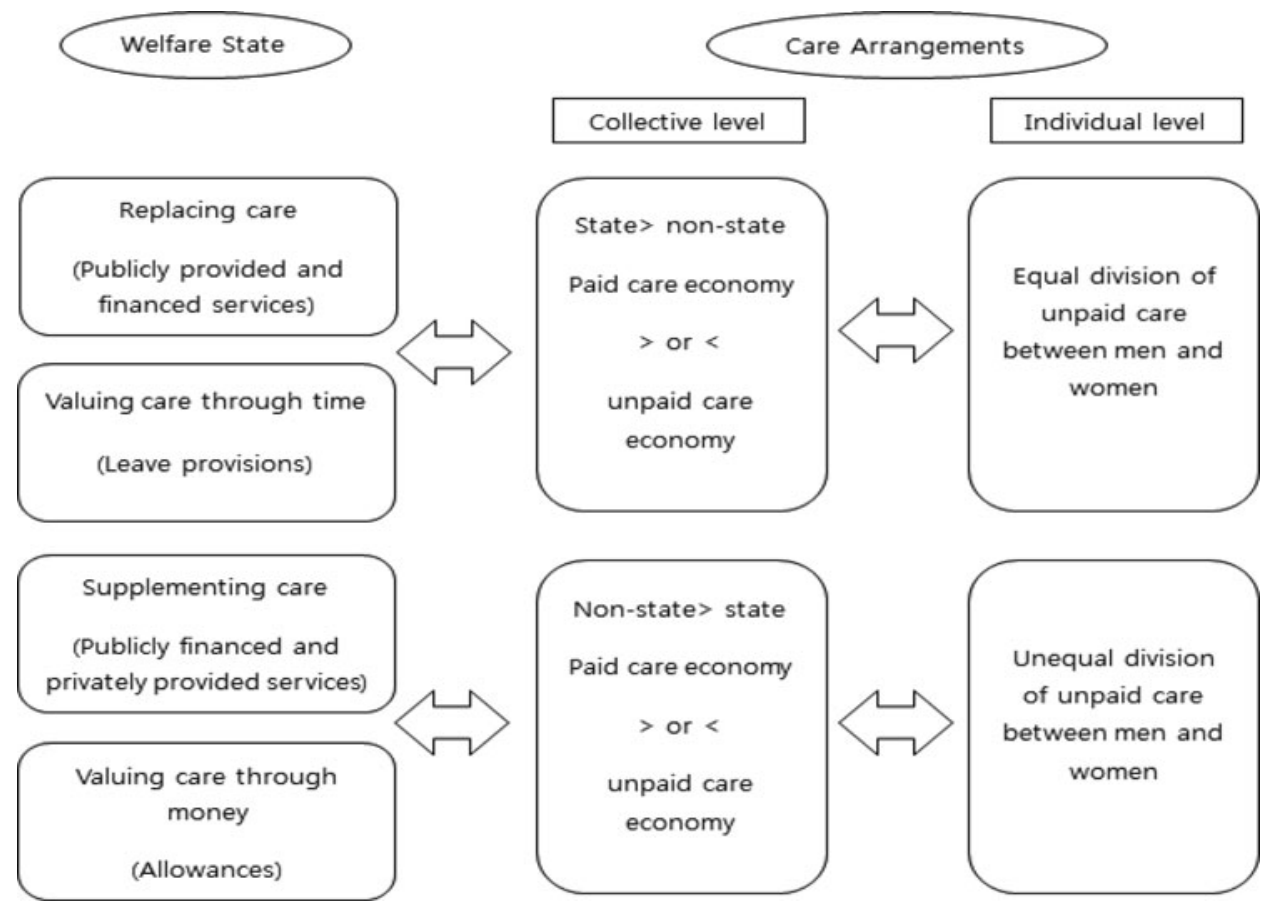

Figure 1. Welfare states and care arrangements at collective and individual levels

Effinger, 2005: 328). Figure 1 illustrates welfare states and care arrangements at collective and individual levels.

\section{Differences and similarities in childcare policies in Japan and Korea}

According to the OECD (2015a), childcare and family have become the third largest arena of public and private mandatory expenditures after old age and health in Japan and Korea. In terms of proportion of the GDP, Japan's expenditures accounted for 1.4 per cent in 2011, and Korea's accounted for 1 per cent. In the social expenditures by family sub-category, expenditures for early childhood care and education (ECEC) increased from 0 per cent to 0.8 per cent between 1990 and 2011 in Korea, and from 0.2 per cent to 0.4 per cent in Japan. Expenditures on leave provisions increased from 0 per cent to 0.1 per cent in Korea and from 0.1 per cent to 0.3 per cent in Japan. Although child allowance increased from 0.1 per cent to 0.7 per cent in Japan, it remained as low as 0 per cent in Korea.

In an attempt to mitigate low fertility, accommodate female labour market participation and enhance work-life balance, the Japanese government extended the scale of childcare services in the 1990s. However, it is important to note that the traditional paradigm of childcare provision remained salient. In this paradigm, childcare is the responsibility of the family, and the role of the state and society should be limited to providing supplementary support for family-centred childcare. In Korea, the number of childcare service providers and users steadily increased after the introduction of the 1991 


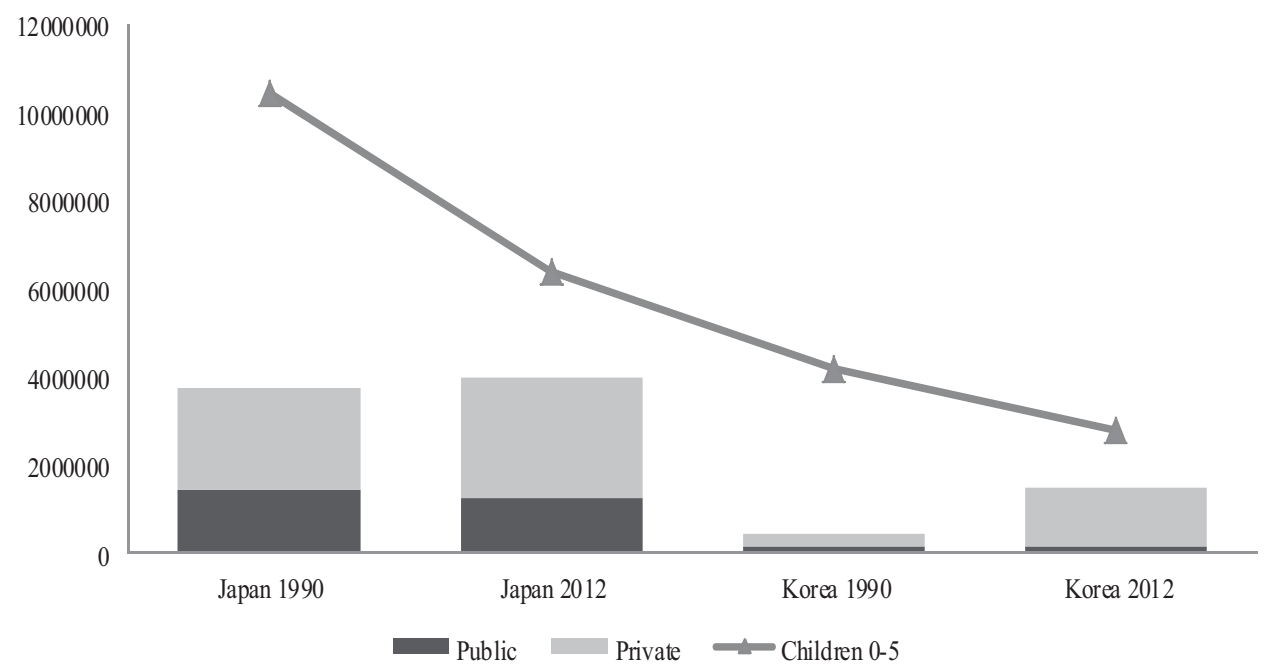

Figure 2. Children in early childhood care and education services and the number of children aged 0-5 in Japan and Korea Sources: MEST and KERI (2010), NIEPR and MEXT (2011), SB (2015), MHW (2005, 2012a), National Statistics Office [NSO] (1990), OECD (2015b).

Infant Care Act (ICA); the deregulation policy and financial support for both providers and users attempted to reverse low fertility and enhance female labour market participation. Service providers continued to grow, and the public financial support coverage was expanded to include middle-income families in the middle of the first decade of the new century; all families, regardless of family income, were included in 2013.

The nature of formal care services differs; Japan has traditionally featured more public services than Korea: in 2000, 51 per cent of Japanese nurseries and kindergartens were public compared to 19.8 per cent in Korea. Over time, the proportion of public service providers has decreased in both Japan and Korea, accounting for 43.4 per cent and 14.1 per cent of total service providers respectively in 2010 (Ministry of Education, Science and Technology and Korean Educational Research Institute (MEST and KERI), 2010; National Institute for Educational Policy Research and Ministry of Education, Culture, Sports, Science and Technology (NIEPR and NEXT), 2011; Ministry of Health and Welfare (MHW), 2012a; Statistics of Bureau (SB), 2015). But cross-national differences in public provisions have remained salient. In addition, in private provisions, nonprofit provision features strongly in Japan, while for-profit provisions dominate in Korea (Japanese Economy Information Division, 2005; An and Peng, 2015). Although the number of children aged nought to five has continually decreased over time (see Figure 2) in both countries, the proportion of children in nurseries and kindergartens increased from 36 per cent to 62 per cent in Japan between 1990 and 2012, and jumped from 11 per cent to 77 per cent in Korea over the same period.

The leave provisions in the two countries differ in their histories and what they offer. Maternity leave in Japan currently offers fourteen weeks at two thirds of the female worker's salary. The unpaid childcare leave law pays 50 per cent of wages. As part of an effort to achieve gender equality in caring responsibilities, the duration is extended to one year and one month if both parents take childcare leave. In Korea, 
fully paid maternity leave is offered for ninety days. A parental leave scheme was introduced in 1987. Unpaid at first, several reforms have resulted in the introduction of, and increase in the rate of, wage replacement, currently 40 per cent of wages, with an upper limit of 1,500 USD per month. Japan's and Korea's full-time equivalent (FTE) of the leave period, if paid at 100 per cent, remained low at 9.3 weeks and 10.5 weeks respectively, below the OECD average (12.4 weeks) in 2013 (OECD, 2015c). FTE paternity leave was 4.3 weeks in Japan but only 0.4 weeks in Korea, compared to the OECD average of 2.7 weeks. Yet for parental leave, both countries' FTEs - twenty-two weeks in Japan and 16.9 weeks in Korea - were higher than the OECD average of 14.5 weeks.

Japan has a much longer history of child allowance. The allowance began in 1971 and aimed to reduce poverty in low income families. In a 2010 revision, coverage was extended to all children from birth to junior high school graduation. Japan's child allowance can be regarded as an example of familialising care (An and Peng, 2015), as recent policy debates indicate the scheme was premised on a strong belief that the responsibility for children's upbringing falls on the parents (i.e. mothers) (Abe et al., 2003). Care allowance is relatively new for Korea, providing benefits since 2009. The free childcare package (giving all families with preschool children the right to receive public financial support in childcare arrangements) initially covered low income families who did not utilise childcare services; the coverage was expanded through subsequent policy reforms to include all children aged nought to five who do not receive childcare services.

\section{Measuring care arrangements: care time mix approach}

To measure where and in what form care is produced across collective and individual levels, we suggest using efficacy of time as a measurement. The care time mix refers to the care configuration among institutions and individuals measured in time; thus, it represents the total societal welfare. The approach has important merits. First, it extends discussions on (re)distributional resources at the individual level by applying time measurement at the collective, institutional level, thus linking care configurations between the two levels. Second, time can be considered an indicator of the economy of welfare, assigning monetary value to unpaid care work (Budlender, 2010). For example, the value of time spent on care for family was estimated to account for approximately 8 per cent of GDP in Japan and Korea (An, 2010; Tamiya and Shikata, 2010). The aggregate care time configuration across institutions and individuals depicts care as paid versus unpaid work, suggesting where and how care is produced and the degree to which care is the article of purchase.

Some caveats are in order, however. First, as the approach is built on the welfare mix (Jenson and Saint-Martin, 2003), it is challenging to draw boundaries between sectors, as care provision responsibilities among the state, market and family are not mutually exclusive (Razavi, 2007). The boundary for institutions is especially blurred as the provision-finance nexus in childcare provisions is far from straightforward. Second, data are not always available on the care time spent by individuals versus formal childcare institutions. Last, the way in which care time is estimated may vary which might result in different outputs (An, 2013). 


\section{Data and measurement}

We measured care by men, care by women, care by family (informal private), care by non-state (formal private), and care by state (public) as follows. We estimated care arrangements for children aged nought to five at a number of points in time: 2001, 2006, 2010 and 2012 for Japan, and 1999, 2004, 2009 and 2013 for Korea.

\section{Care by men and women}

Japan and Korea have conducted time use surveys to measure time spent on activities. From these, we extracted data on the weekly average time spent on childcare by men and women aged between twenty and forty-nine (NSO, 2015; SB, 2015). Childcare in the surveys in both countries included activities such as physical care, reading, playing, teaching and nursing in terms of both main and simultaneous activities. As noted above, we considered the 2001, 2006 and 2011 surveys for Japan; we used the average times for 2011 to estimate the individuals' care time in 2010 and 2012. For Korea, we used the 1999, 2004 and 2009 time use surveys, with the 2009 results representing the 2013 results. For total care time by men and women, we multiplied the number of children aged nought to five by the average care time by men and women respectively. We included the household composition, i.e. couple (cohabitating and married) or single parent households, in the estimation. In 2007, in Japan, about 87.7 per cent of children under fifteen lived in either cohabitating or married households, with the rest in single parent households (OECD, 2011). In Korea, approximately 98 per cent of preschool children lived in either cohabiting or married households in 2005 (Ministry of Gender Equality (MGE), 2005).

From the national statistics of both countries, we obtained the total population of children aged nought to five; we calculated the number aged nought to five in couple households and single households based on the household composition. Total care time by men was calculated using the number of children in couple households and the average time spent on care by men. Total care time by woman was calculated considering the total number of preschool children and the average female care time; single parent households were assumed to be single-mother households for simplicity, given the lack of accurate information. Specifically, for example, in Korea, 98 per cent of preschool children receive care from both father and mother, while 2 per cent receive care from the mother only.

\section{Care by family (informal private)}

At the institutional level, care by family is informal, private, and comprises care by the father and mother. In other words, the total family care time is an aggregate of total male and total female care time. Accordingly, the family care time also reflects crossnational variances in household compositions. Care by grandparents or other relatives is an informal private care source, but is not considered in this study because the time use surveys we drew on do not specifically collect data on the time spent on care by grandparents or other relatives. 


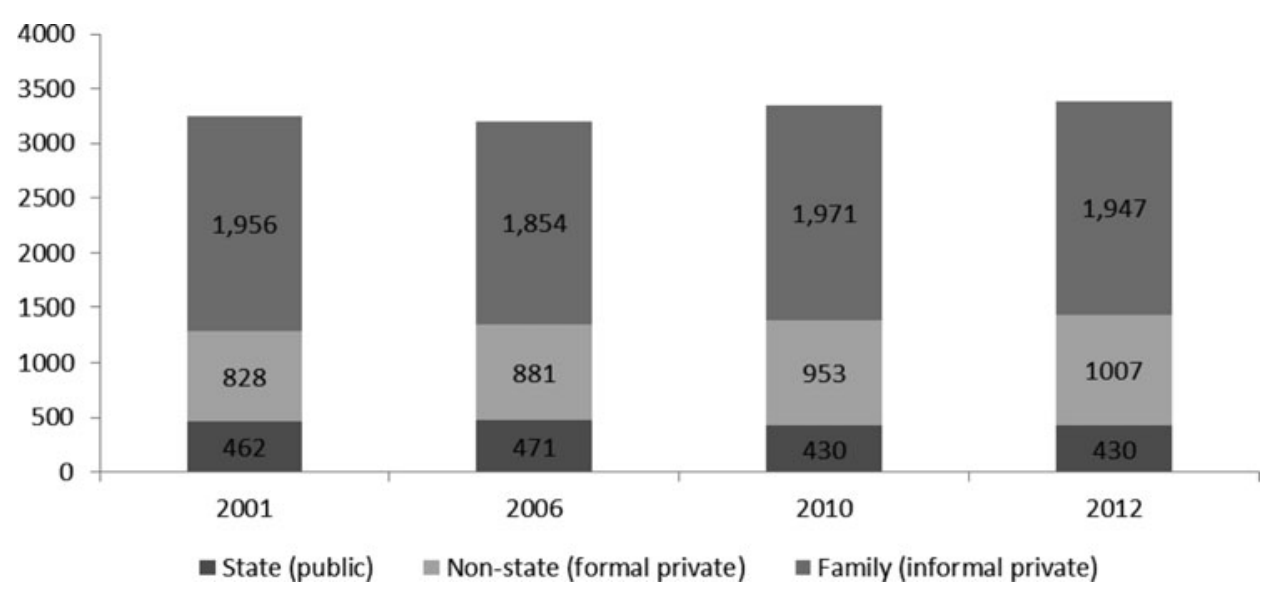

Figure 3. Total care time by state, non-state and family in Japan $(100,000$ minutes, per day)

Care by state (public) and non-state (formal private)

We divided services at the institutional level into state (public) and non-state (formal private). Non-state may be subdivided into for-profit and not-for-profit sectors, but given the lack of comparable data, we restricted the analysis to formal private provision. Japan and Korea offer national statistics on childcare provision; we regarded all other providers as formal private except the public provision. We estimated state and non-state care by considering the number of children in nurseries and kindergartens (MHW, 2005, 2013; NIEPR and MEXT, 2011; SB, 2015). In Korea, the average daily childcare service in public nurseries in 2005, 2009 and 2012 was 453, 471 and 472 minutes respectively; private nurseries came in at 454, 483 and 471 minutes respectively. For public kindergartens, it was 338, 401 and 452 minutes respectively, and for private kindergartens, 354, 395, and 426 minutes respectively (MGE, 2005; Ministry of Health, Welfare and Family (MHWF), 2009; MHW, 2012b). The national report in Japan gives the business hours of day care centres (Ministry of Health, Labour and Welfare (MHLW), 2010). In both countries, business hours of the majority of nurseries (62 per cent in Japan and 73 per cent in Korea) are between eleven and twelve hours per day (MHWF, 2009; MHLW, 2010). Based on this information, we approximated Japan's average daily service hours and divided the nursery service hours in half for kindergartens, based on descriptions in national reports (NIEPR and MEXT, 2011). For Korea in 1999, we used data from 2004. For Japan, we uniformly used the data for the four points in time. Based on these data, it seems public and formal private care time, particularly in Japan, are subject to changes in the number of children receiving the services.

\section{Results}

Care arrangements between institutions

Care time by state, non-state, and family providers is summarised in Figures 3 and 4 for Japan and Korea. As the figures make clear, the care time by family in Japan decreased by the middle of the first decade of the 2000s and then reversed direction. By way of contrast, 


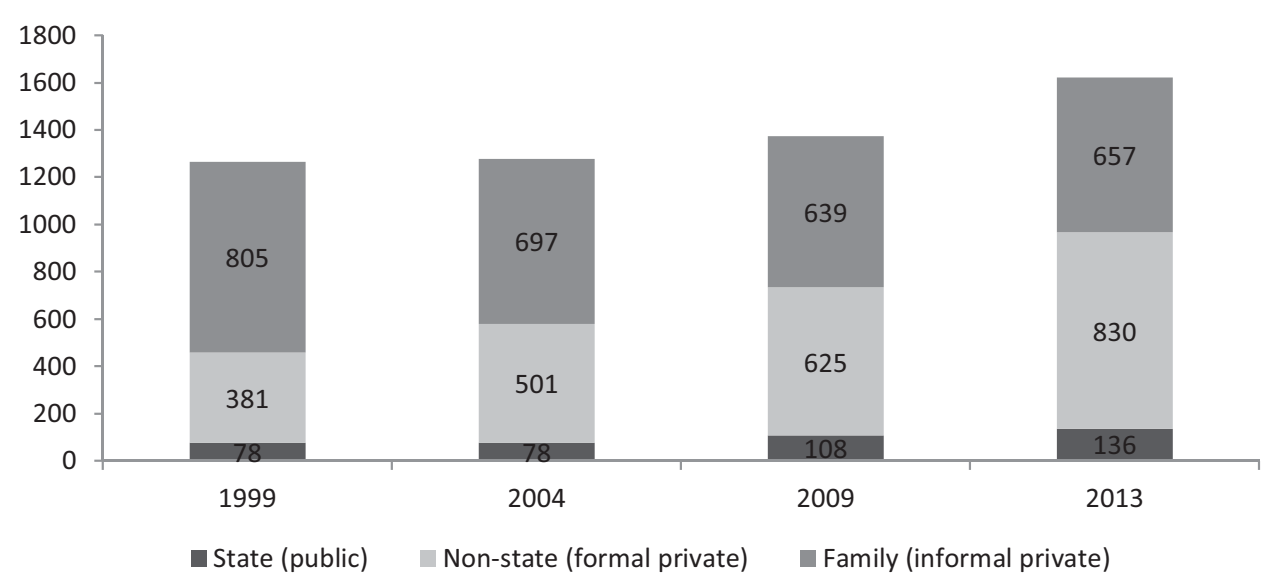

Figure 4. Total care time by state, non-state and family in Korea (100,000 minutes, per day)

care by non-state provision continually increased. As with family care time, care by state increased, but then changed direction. Total care time across state, non-state and family marginally increased by 4.2 per cent between 2001 and 2012. The reversed pattern of the family role can be attributed to the care familialisation occasioned by reforms in child allowance and leave provisions.

In Korea, care time by state and non-state continually increased over time, with a marked increase in the non-state sector. As in Japan, care by family decreased by the end of the first decade of the 2000s before reversing. In total, care time across all institutions increased by an estimated 28.4 per cent between 1999 and 2013. The reversed pattern of familialised care can be attributed to the provision of an in-home care allowance. In 2010, the proportion of in-home care allowance recipients was 2 per cent of children under age five; this increased to 38 per cent in 2013 (MHW, 2010, 2013). Approximately 83 per cent of the in-home care allowance recipients were children up to three years of age in 2013.

Figure 5 shows how care arrangements compare proportionally across institutions and over time in both countries. The share provided by the state decreased from 14 to 12 per cent in Japan, while the share provided by non-state providers increased from 26 per cent to 30 per cent. The family share decreased from 60 per cent to 58 per cent, but family remained the primary locus of care production in Japanese society. In contrast, the primary location of care production shifted from family to the non-state sector, which is largely for-profit provision in Korea. The share provided by the state increased marginally, by 2 per cent, during the last decade or so. At the same time, the non-state share increased from 30 per cent to 51 per cent, producing more than half of total care in the society. In contrast, the role of the family decreased from 64 per cent to 41 per cent.

In other words, at the beginning of the new century, the basis of care provision was largely unpaid work in both Japan and Korea (60 per cent and 64 per cent respectively), but recent changes in childcare policies have led to divergent outcomes. Korean society has transformed from family $>$ non-state $>$ state to non-state $>$ family $>$ state, whereas Japanese society has maintained the family $>$ non-state $>$ state pattern. It is also noteworthy that the nature of care as paid work differs between the two countries. Although care production 

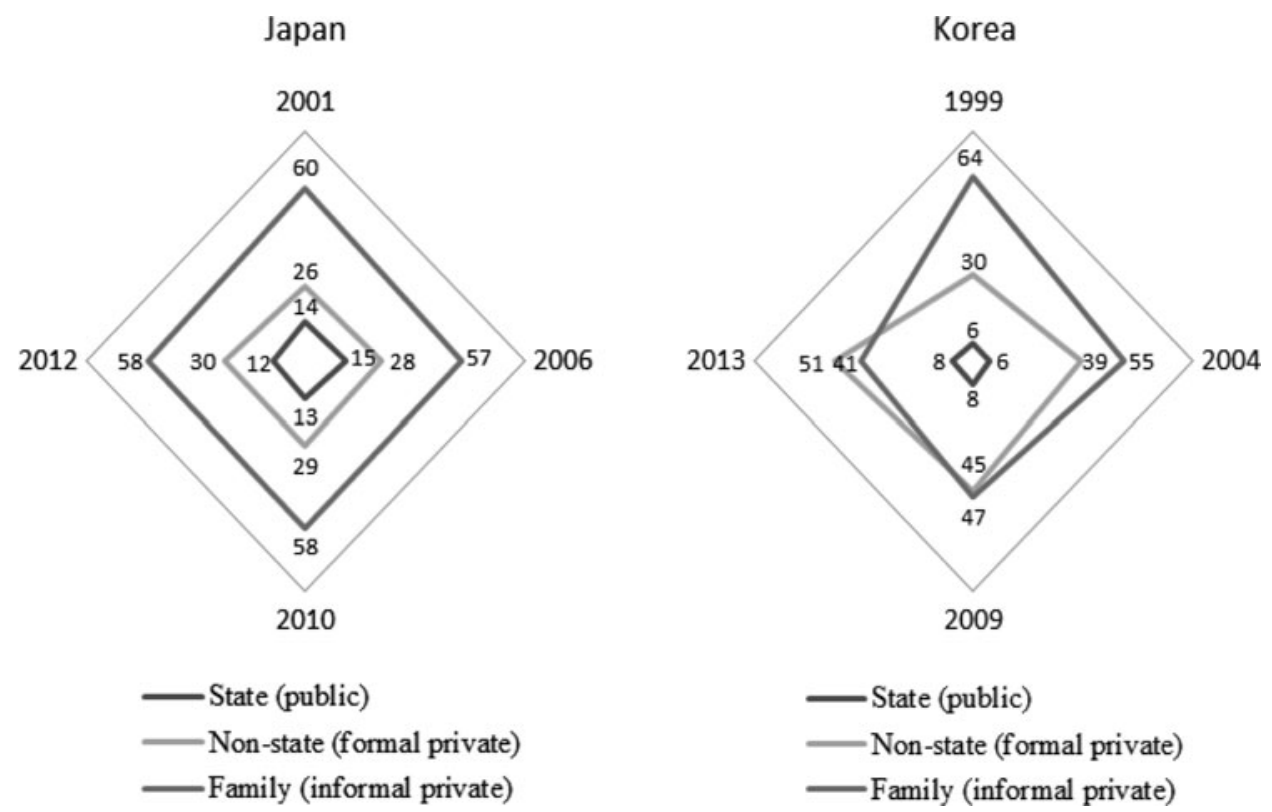

Figure 5. Care arrangements between state, non-state and family in Japan and Korea

as paid work in the non-state sector is larger than in the state in both countries, the Korean care regime is exclusively marketised, while the Japanese regime features more paid care work generated by the state.

\section{Care arrangements between institutions and individuals}

At the beginning of the new millennium, females within the household were the primary caregivers, accounting for 42 per cent of caregiving in Japan and 44 per cent in Korea (see Figure 6). The least common care provider in Japan and Korea was the state, accounting for 14 per cent and 6 per cent respectively. Put differently, the care arrangements between institutions and individuals were configured as female $>$ non-state $>$ male $>$ state in both countries.

Over time, in Japan, the role of the state has decreased while that of the non-state increased. At the same time, the share of care by males remained the same, while the female role decreased before reversing to show an increase. In Korea, meanwhile, the role of the state increased marginally, the share of the non-state sector increased dramatically, and the role of males and females decreased substantially. Considering all these data together, over approximately a decade, the two counties displayed divergent patterns of care arrangements: Japan sustained its female $>$ non-state $>$ male $>$ state order, while Korea transformed to non-state $>$ female $>$ male $>$ state.

There are other important similarities and differences in care arrangements at the individual level. A similarity is that the unpaid care economy remained gendered; about two thirds of the total unpaid care economy in both countries was assumed by women. A difference is the varying pattern of changes in time spent caring by males and females. In 


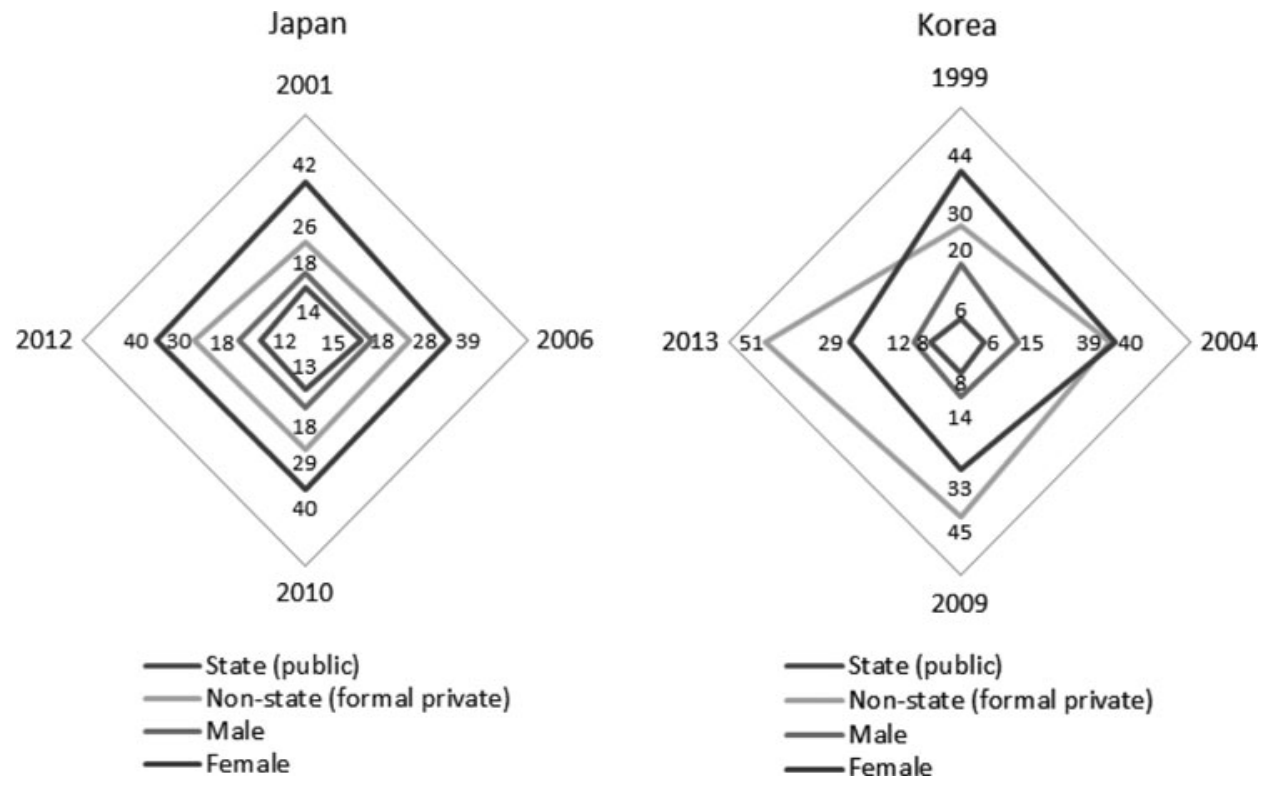

Figure 6. Care arrangements between state, non-state, male and female

Japan, the role of males increased marginally, while the role of females within households decreased. Care by males initially accounted for 30 per cent of the unpaid care economy in 2001; this increased to 31 per cent in 2012. In Korea, the role of men in the unpaid care economy was slightly larger than Japan in 1999, accounting for 31.3 per cent. Over time, the role of men decreased slightly, accounting for 29.3 per cent in 2013. In addition, women's contribution in unpaid work to the care economy was primary in both countries; however, after about ten years, unpaid care by females ranked as the second source of care production in Korea while it remained the primary form of care production in Japan.

\section{Discussion and conclusion}

This article analyses care arrangements at collective and individual levels in Japan and Korea using a care time mix approach. It finds diverging patterns in the evolution of care arrangements between the two East Asian welfare states. At the beginning of the new millennium, both countries valued an unpaid care economy. A little over ten years later, the two welfare states organise care differently. Japan's care arrangements have remained more or less the same, with marginal changes. For the most part, the welfare state continues to prefer an unpaid care economy by family, not a paid care economy. It remains strongly gendered, with unpaid care work provided by females within families. In contrast, Korea's unpaid care economy, fuelled by family and females, has been transformed into a paid care economy. As in Japan, however, care as unpaid work remains strongly gendered.

Both countries have supplemented care, but Japan has tried to replace care more than Korea through publicly financed and provided formal services. Notably, its policy inscribes the importance of female labour for a nation's economy. Good quality services are imperative, and here the state has played an important role. Japan has also been 
more generous in supporting family through leave provisions to encourage individuals to reconcile work and family life (Seeleib-Kaiser and Toivonen, 2011). Arguably, compared to Korea, these factors may generate a societal atmosphere wherein care is shared by men and women within the household, as shown in the increased role of Japanese fathers. In part, this may be reflected in the difference in time spent by men between the countries; Japanese men spent ninety-one minutes in 2001 and 109 minutes in 2011, while Korean fathers spent sixty-three minutes in 1999 and seventy-two minutes in 2009. At this point, however, as shown in Figure 6, the portion of non-state increased overtime supports the idea of supplementing care by family. As a result, care as unpaid work continues to remain women's labour. At the same time it should be noted that the role of family as care provider has been encouraged through reforms in the child allowance (An and Peng, 2015).

In contrast, Korea has moved to a paid care economy based on the idea of supplementing care by family through the extensive publicly financed services in the for-profit sector. As such, the quality of services is not strictly managed by regulations and fails to bring mothers into paid work. When this is combined with the workplace culture, which is not gender friendly (OECD, 2012), working women (mostly full time) might find it difficult to balance work life with family, as care has not been effectively replaced by either formal institutions or the male partner within families. Supplementing care through universal financial support for childcare services might, ironically, have been influential in sustaining the gender division: fathers may feel no obligation to actively intervene in childcare, as their male breadwinning role - namely, securing finances for childcare - has been taken away by the state, suggested by the decreased role of males to both the unpaid care economy and the entire care economy. If so, valuing the role of family through an allowance may reinforce the role of women as primary caregivers.

The findings suggest that neither country has formed a universal carer model; nor is the traditional male breadwinner and female caregiver the dominant family model. Rather, in both countries, the care expansion may have generated the unsupported universal earner and female caregiver model. That said, Japan may have generated more part-time employment than Korea, as it has relatively stronger ideational orientations towards work and family reconciliation accompanied replacement care. The OECD (2011) found that the employment rate of women between the ages of twenty-five and fifty-four in Japan was 67.6 per cent in 2009, with 30.5 per cent employed part time. In contrast, the employment rate of women between the ages of twenty-five and fifty-four in Korea was 59.8 per cent, with only 11 per cent employed part-time (OECD, 2011). In addition, approximately 48 per cent of Japanese couple households with children aged nought to fifteen had a single full time earner in 2011 (OECD, 2015c). Therefore, we suggest the childcare expansions in Japan have generated the co-existence of different family models: unsupported full time dual-earner and female caregiver model, unsupported one-and-a-half earner and female caregiver model, and male breadwinner and supported female caregiver model. Meanwhile, in 2013, the proportion of male breadwinner families in Korea was approximately 57 per cent of all married households whose heads were between the ages of fifteen and forty-nine (NSO, 2013). We suggest supplementing the caring role of the family and reinforcing women's location in the home may have generated the co-existence of the unsupported dual-earner and female caregiver model and the male breadwinner and (perhaps supported) female caregiver model. We conclude that cross-national variances in welfare states and gender might be manifested in the types of 
theoretical ideal family model being supported, and welfare states may differ in terms of the proportional variances of the various family models.

The transformation of care arrangements in Korea is limited, as the welfare state has not effectively addressed the gender inequalities in paid versus unpaid work. The state's universal financial support may be contributing to a horizontal redistribution amongst families, thereby generating social inclusiveness. However, this also signals the appearance of new forms of inequalities. Women's gainful employment in service sector development is featured in an irregular form of employment with low wages and relatively shorter working lives. Female care service workers might find themselves disadvantaged compared to working women in other industries. In the end, gender inequality in Korea might become an issue in both paid and unpaid work. At the same time, Japan's continued equilibrium in an unpaid care economy suggests the state has not fully addressed the gender inequalities of paid versus unpaid work. The growing tendency towards the marketisation of care may indicate the possibility of the division of society based on women's inequality.

It seems that in both countries childcare expansions have allowed different forms of family models to coexist; consequently, social and economic inequalities between families could become significant features of the social structure. Concurring with EspingAndersen (2009), we suggest the changes during the last decade or so have only been partially successful; further social policy developments are required to avoid a deleterious equilibrium or the widening of new forms of inequality. In addition, the transformation to the paid care economy in Korea and its growth through marketisation or market mechanisms in Japan indicate that the issues of user empowerment, service quality and cost-effectiveness will be on the agenda in restructuring childcare policies in the future.

It is unwise to assume higher social expenditures on care and family equate to a higher degree of a paid care economy. Total social expenditures have always been higher in Japan than Korea; Japan has sustained its unpaid care economy, whereas Korea has not. Welfare states replace, supplement and/or value care by family, and there are crossnational variances in both degree and dimension. In addition, welfare states can support varying family models. For these reasons, it might be worth recasting welfare states and care arrangements in welfare states in Europe, and comparing and contrasting the welfare states in the East and the West.

\section{References}

Abe, M., Hamamoto, C. and Tanaka, S. (2003) Reconciling Work and Family: Issues and Policies in Japan, Conditions of Work and Employment Series No. 5, Geneva: International Labour Office.

Anttonen, A. and Sipilä, J. (1996) 'European social care services: is it possible to identify models?', Journal of European Social Policy, 6, 2, 87-100.

An, M. Y. (2010) 'Republic of Korea', in D. Budlender (ed.), Time Use Studies and Unpaid Care Work, New York: UNRISD/Routledge, pp. 118-41.

An, M. Y. (2013) 'Childcare expansion in East Asia: changing shape of the institutional configurations in Japan and South Korea', Asian Social Work and Policy Review, 7, 1, $28-43$.

An, M. Y. and Peng, I. (2015) 'Diverging paths? A comparative look at childcare policies in Japan, South Korea and Taiwan', Social Policy and Administration, DOI: 10.1111/spol.12128.

Budlender, D. (2010) (ed.) Time Use Studies and Unpaid Care Work, New York: UNRISD/Routledge. 
Ciccia, R. and Bleijenbergh, I. (2014) 'After the male breadwinner model? Childcare services and the division of labor in European countries', Social Politics: International Studies in Gender, State and Society, 21, 1, 50-79.

Daly, M. (2010) 'Shifts in family policy in the UK under New Labour', Journal of European Social Policy, 20, 5, 433-43.

Daly, M. (2011) 'What adult worker model? A critical look at recent social policy reform in Europe from a gender and family perspective', Social Politics: International Studies in Gender, State and Society, $18,1,1-23$.

Daly, M. and Lewis, J. (2000) 'The concept of social care and the analysis of contemporary welfare states', British Journal of Sociology, 51, 2, 281-98.

Esping-Andersen, G. (2009) Incomplete Revolution: Adapting Welfare States to Women's New Roles, Cambridge: Polity Press.

Huber, E. and Stephens, J. D. (2001) Development and Crisis of the Welfare State: Parties and Policies in Global Markets, Chicago: University of Chicago Press.

Japanese Economy Information Division (2005) 'Child Day Care Industry in Japan', JETRO Japan Economic Monthly, http://www.jetro.go.jp/ext_images/en/reports/market/pdf/2005_69_p.pdf [accessed 10.01.2015].

Jenson, J. and Saint-Martin, D. (2003) 'New routes to social cohesion? Citizenship and the social investment state', Canadian Journal of Sociology, 28, 1, 77-99.

Korpi, W. (2000) 'Faces of inequality: gender, class and patterns of inequalities in different types of welfare states', Social Politics: International Studies in Gender, State and Society, 7, 2, 127-91.

Leitner, S. (2003) 'Varieties of familialism: the caring function of the family in comparative perspective', European Societies, 5, 4, 353-75.

Lewis, J. (1992) 'Gender and the development of welfare regimes', Journal of European Social Policy, 2, 3, 159-73.

Lewis, J. (2001) 'The decline of the male breadwinner model: implications for work and care', Social Politics: International Studies in Gender, State and Society, 8, 2, 152-69.

Lewis, J. (2013) 'Continuity and change in English childcare policy 1960-2000', Social Politics: International Studies in Gender, State and Society, 20, 3, 358-86.

Lewis, J. and Campbell, M. (2007) 'Work/family balance policies in the UK since 1997: a new departure?', Journal of Social Policy, 36, 3, 365-81.

Lundberg, S. and Pollak, R. (1996) 'Bargaining and distribution in marriage', Journal of Economic Perspectives, 10, 4, 139-58.

Mahon, R. (2002) 'Child care: toward what kind of "social Europe"?', Social Politics: International Studies in Gender, State and Society, 9, 3, 343-79.

Mahon, R., Anttonen, A., Bergqvist, C., Brennan, D. and Hobson, B. (2012) 'Convergent care regimes? Childcare arrangements in Australia, Canada, Finland and Sweden', Journal of European Social Policy, $22,4,419-31$.

Ministry of Education, Science and Technology and Korean Educational Research Institute (MEST and KERI) (2010) Education Statistical Yearbook, Seoul: MEST and KERI.

Ministry of Health, Labour and Welfare (MHLW) (2010) Survey of Social Welfare Institutions, Tokyo: MHLW.

Ministry of Gender Equality (MGE) (2005) Survey on Childcare, Seoul: MGE.

Ministry of Health and Welfare (MHW) (2005) Childcare Statistics, Seoul: MHW.

Ministry of Health and Welfare (MHW) (2010) Childcare Statistics, Seoul: MHW.

Ministry of Health and Welfare (MHW) (2012a) Childcare Statistics, Seoul: MHW.

Ministry of Health and Welfare (MHW) (2012b) Survey on Childcare, Seoul: MHW.

Ministry of Health and Welfare (MHW) (2013) Childcare Statistics, Seoul: MHW.

Ministry of Health, Welfare and Family (MHWF) (2009) Survey on Childcare, Seoul: MHWF.

National Institute for Educational Policy Research and Ministry of Education, Culture, Sports, Science and Technology (NIEPR and MEXT) (2011) Preschool Education and Care in Japan, http:// 
www.nier.go.jp/English/EducationInJapan/Education_in_Japan_files/201109 ECEC.pdf [accessed 02.01.2015].

National Statistics Office (NSO) (1990) Population Survey, Seoul: NSO.

National Statistics Office (NSO) (2013) Trends on Dual Earner Households, Seoul: NSO.

National Statistics Office (NSO) (2015) Time Use Survey, http://kosis.kr/statisticsList/statisticsList_01 List. jsp?vwcd=MT_ZTITLE\&parentld=D [accessed 02.01.2015].

Organisation for Economic Co-operation and Development (OECD) (2011) Doing Better for Families, Paris: OECD.

Organisation for Economic Co-operation and Development (OECD) (2012) Closing the Gender Gap: Act Now, Paris: OECD.

Organisation for Economic Co-operation and Development (OECD) (2015a) OECD Social Expenditure Database, http://www.oecd.org/social/expenditure.htm [accessed 10.01.2015].

Organisation for Economic Co-operation and Development (OECD) (2015b) Population by Age and Sex, http://stats.oecd.org/Index.aspx?DataSetCode=RPOP [accessed 03.01.2015].

Organisation for Economic Co-operation and Development (OECD) (2015c) OECD Family Database, http://www.oecd.org/social/soc/oecdfamilydatabase.htm [accessed 10.01. 2015].

Pfau-Effinger, B. (2005) 'Welfare state policies and the development of care arrangements', European Societies, 7, 2, 321-47.

Razavi, S. (2007) The Political and Social Economy of Care in a Development Context: Conceptual Issues, Research Questions and Policy Options, Gender and Development Programme Paper No. 3, Geneva: United Nations Research Institute for Social Development.

Saxonberg, S. (2012) 'From defamilization to degenderization: toward a new welfare typology', Social Policy and Administration, 47, 1, 26-49.

Seeleib-Kaiser, M. and Toivonen, T. (2011) 'Between reforms and birth rates: Germany, Japan and family policy discourse', Social Politics: International Studies in Gender, State and Society, 18, 3, 331-60.

Statistics of Bureau (SB) (2015) Japan Statistical Yearbook 2015, http://www.stat.go.jp/ english/data/nenkan/1431-20.htm [accessed 20.07.2015].

Szelewa, D. and Polakowski, M. P. (2008) 'Who cares? Changing patterns of childcare in central and Eastern Europe', Journal of European Social Policy, 18, 2, 115-31.

Tamiya, Y. and Shikata, M. (2010) 'Analysis of time use surveys on work and care in Japan', in D. Budlender (ed.), Time Use Studies and Unpaid Care Work, New York: UNRISD/Routledge, pp. 142-70.

Tavora, I. (2012) 'The southern European social model: familialism and the high rates of female employment in Portugal', Journal of European Social Policy, 22, 1, 63-76.

Williams, F. and Brennan, D. (2012) 'Care, markets and migration in a globalizing world: introduction to the special issue', Journal of European Social Policy, 22, 4, 355-62. 